\title{
Keterlaksanaan Aspek Penelitian Pembelajaran Biologi SMAN Kelas X Se-Kota Yogyakarta Berdasarkan Latar Belakang Akademik Guru
}

\author{
Desy Aquina ${ }^{1} *$, Bambang Subali ${ }^{2}$ \\ ${ }^{1}$ SMA Negeri 1 Prembun. Jalan Wadaslintang No. 12, Sidogede, Kebumen, Jawa Tengah, Indonesia \\ ${ }^{2}$ Jurusan Pendidikan Biologi, Universitas Negeri Yogyakarta. Jalan Colombo No. 1, Karangmalang, \\ Yogyakarta 55281, Indonesia \\ * Korespondensi Penulis. Email: desy_aquina@yahoo.co.id, Telp: +6285743374924
}

\begin{abstract}
Abstrak
Penelitian ini bertujuan untuk mengetahui (1) persepsi guru terhadap keterlaksanaan membelajarkan aspek penelitian dalam pembelajaran biologi SMA kelas X di SMAN se-Kota Yogyakarta di tinjau dari penilaian dokumen, observasi, dan kecocokannya dengan persepsi siswa; (2) keterlaksanaan kegiatan membelajarkan aspek penelitian dalam pembelajaran biologi SMA kelas X hubungannya dengan latar belakang akademik guru. Jenis penelitian ini merupakan penelitian evaluasi dengan model discrepancy. Sebagai subjek penelitian adalah seluruh guru Biologi kelas X SMA N se-Kota Yogyakarta yang berjumlah 8 orang dan 270 siswa kelas X yang diambil secara acak, satu sekolah diambil satu kelas. Teknik pengumpulan data menggunakan model triangulasi yaitu kuesioner, penilaian dokumen, dan observasi, analisis data dengan teknik deskriptif kuantitatif. Hasil penelitian menyatakan bahwa baik ditinjau dari persepsi guru, persepsi siswa, penilaian dokumen, maupun observasi: (1) menurut persepsi guru, 75\% guru biologi kelas X di SMA N se-Kota Yogyakarta telah membelajarkan aspek penelitian pada kriteria hampir selalu dilakukan dan $25 \%$ guru membelajarkan aspek penelitian pada kriteria sering dilakukan, hal ini cocok dengan hasil penilaian dokumen, observasi, dan persepsi siswa; (2) keterlaksanaan membelajarkan aspek penelitian pada pembelajaran biologi bergantung pada latar belakang akademik guru.
\end{abstract}

Kata Kunci: keterlaksanaan, aspek penelitian, latar belakang akademik

\section{The Implementation of Research Aspects in Biology Courses for Tenth Graders of SSHS in Yogyakarta Based on Academic Background of the Teachers}

\begin{abstract}
This study aims to determine: (1) teacher's perception about the feasibility of the teaching aspects of research in biology instruction in class X of State Senior High School in Yogyakarta in term of document assessment, observation, and the compatibility to the perception of the students and (2) the feasibility of the teaching aspects of research in biology instruction related to the academic background of teachers teaching in class $X$ of state senior high school in Yogyakarta. The study employs a discrepancy evaluation model. The subjects consist of all biology teachers of tenth graders of SMANs in Yogyakarta numbering 8 teachers and 270 students. They were taken in random; one school one class. Data collection was conducted using a triangulation model:questionnaire, document assessment, and observation. Data analysis was done using descriptive technique. The results indicate that (1) according to the teacher's perception, 75\% biology teachers in state Senior High School in Yogyakarta have taught the aspects of research on criteria almost always doing and 25\% biology teachers have taught aspects of research on criteria often doing, which fits with the results of the document assessments, observations, and the perceptions of the students; (2) the feasibility on the teaching research aspects on biology learning does depend on the academic background of the teachers.
\end{abstract}

Keywords: implementation, research aspects, teachers' academic background

How to Cite: Aquina, D., \& Subali, B. (2016). Keterlaksanaan aspek penelitian pembelajaran biologi SMAN kelas X se-Kota Yogyakarta berdasarkan latar belakang akademik guru. Jurnal Inovasi Pendidikan IPA, 2(1), 111. doi:http://dx.doi.org/10.21831/jipi.v2i1.8803

Permalink/DOI: http://dx.doi.org/10.21831/jipi.v2i1.8803 


\section{PENDAHULUAN}

Dalam rangka peningkatan kesejahteraan dan profesionalitas guru, pemerintah berupaya memberikan stimulan kepada sekolah melalui berbagai program peningkatan, diantaranya adalah pemberian tunjangan profesi guru. Tunjangan profesi adalah tunjangan yang diberikan kepada guru dan dosen yang memiliki sertifikat pendidik sebagai penghargaan atas profesionalitasnya (Peraturan Pemerintah Republik Indonesia Nomor 41 Tahun 2009 Tentang Tunjangan Profesi Guru dan Dosen). Setelah guru dinilai lulus dari proses sertifikasi dan pelatihan, maka ia berhak mendapatkan tunjangan profesi tersebut. Tujuannya adalah agar guru dapat meningkatkan profesionalitas, kompetensi, dan kinerjanya sehingga dapat mewujudkan mutu pendidikan nasional.

Kebijakan mengenai pemberian tunjangan profesi guru dan dosen, menjadi upaya guru untuk meningkatkan profesionalitasnya. Secara umum ada 4 standar pengembangan profesional guru sains menurut NSES (1996, p.1), yaitu (1) mempelajari materi sains esensial melalui pandangan dan metode inkuiri; (2) mengintegrasikan pengetahuan sains, belajar, pedagogi, dan karakteristik siswa, serta menerapkannya dalam pembelajaran sains; (3) membangun pemahaman dan kemampuan untuk belajar sepanjang hayat; dan (4) program pendidikan guru sains harus koheren dan terintegrasi antara preservice dan inservice. Apabila empat standar tersebut sudah berhasil ditingkatkan, harapannya guru mampu menguasai materi pembelajaran secara luas dan mendalam yang memungkinkan membimbing siswa memenuhi standar kompetensi yang ditetapkan dalam Standar Nasional Pendidikan.

Harapan untuk dapat membimbing siswa memenuhi standar kompetensi, guru Biologi yang profesional seharusnya menyediakan berbagai pengalaman belajar untuk memahami konsep dan membelajarkan keterampilan proses sains yang terkait dengan kehidupan makhluk hidup. Permendiknas Nomor 22 Tahun 2006 menyebutkan bahwa keterampilan proses sains meliputi keterampilan mengamati, mengajukan hipotesis, menggunakan alat dan bahan secara baik dan benar dengan selalu mempertimbangkan keamanan dan keselamatan kerja, mengajukan pertanyaan, menggolongkan dan menafsirkan data, serta mengkomunikasikan hasil temuan secara lisan atau tertulis, menggali dan memilah informasi faktual yang relevan untuk menguji gagasan-gagasan atau memecahkan masalah sehari-hari.

Bersumber pada taksonomi yang dikemukakan oleh Bryce et. al. (1990, p.2), dimensi keterampilan proses sains dapat dibedakan menjadi tiga, yaitu keterampilan dasar (basic skill), keterampilan mengolah/ memroses (process skill), dan keterampilan menginvestigasi (investigation skill). Sementara menurut Rezba et. al. (1995, p.vii) dimensi keterampilan proses sains dapat dibedakan menjadi dua, yaitu keterampilan proses sains dasar (basic science process skill) dan keterampilan proses sains yang terintegrasi (integrated science process skill). Dengan demikian, siswa secara bertahap harus dilatih menguasai keterampilan proses sains mulai dari keterampilan dasar sampai keterampilan menginvestigasi.

Sesuai dengan apa yang tersirat dalam Permendiknas Nomor 22 Tahun 2006, siswa di Sekolah Dasar (SD) seharusnya sudah dilatih menguasai keterampilan proses sains dasar dalam bidang IPA pada tingkatan dasar seperti keterampilan mengamati, mengukur, dan menyimpulkan data. Pada jenjang Sekolah Menengah Pertama (SMP) keterampilan dasar yang sudah dikuasai selama belajar di SD menjadi modal untuk mempelajari keterampilan proses sains menengah yang berupa keterampilan mengolah/memroses, yaitu keterampilan memilih prosedur. Di SMA diharapkan keterampilan proses sains lanjut yang berupa keterampilan berinvestigasi sudah diaplikasikan dalam penyelidikan melalui metode observasi/eksperimen sederhana guna memecahkan permasalahan Biologi yang dihadapi. Hal ini didukung dengan adanya rumusan SK dan KD dalam mata pelajaran Biologi SMA yang secara eksplisit menuntut siswa dapat merencanakan, melaksanakan, dan melaporkan eksperimen untuk topik tertentu. Contohnya pada SK nomor 1 Kelas XII Semester 1 Mata Pelajaran Biologi.

Merealisasikan tuntutan tersebut, guru harus kompeten dalam mencari cara bagaimana membelajarkan aspek penelitian (keterampilan proses sains dasar) dan prosedur penelitian (keterampilan proses sains terintegrasi) pada siswa sesuai dengan jenjang pendidikan dan jenjang kelas. Ada dua faktor yang dapat mempengaruhi kompetensi guru yaitu faktor internal (meliputi latar belakang akademik, pengalaman mengajar, etos kerja, penataran, dan pelatihan) dan faktor eksternal (meliputi iklim kerja, kebijakan organisasi, lingkungan sosial kerja, sarana dan prasarana). Faktor-faktor tersebut saling berinteraksi 


\section{Jurnal Inovasi Pendidikan IPA, 2 (1), 2016 - 3}

Desy Aquina, Bambang Subali

dan mempengaruhi kompetensi guru dalam mengajar.

Seorang guru akan dapat melaksanakaan tugasnya dengan baik apabila memiliki pengetahuan dan keterampilan serta wawasan yang luas dalam bidangnya. Demikian juga seorang guru, dapat melaksanakan tugasnya dengan baik jika memiliki pengetahuan dan keterampilan yang memadai sesuai dengan latar belakang akademik yang telah ditempuhnya, baik pendidikan formal maupun pendidikan non formal. Guru pemula dengan latar belakang akademik keguruan akan lebih mudah dalam menyesuaikan diri dengan lingkungan sekolah, karena telah dibekali seperangkat teori pendukung pengabdiannya. Kalaupun ditemukan kesulitan-kesulitan, hanya aspek-aspek tertentu saja dan itu adalah hal yang wajar. Jangankan guru pemula, bagi guru yang berpengalaman pun tidak pernah terhindar dari berbagai masalah-masalah di sekolah. Perbedaannya terletak pada tingkat kesulitannya. Tingkat kesulitan semakin hari semakin berkurang seiring dengan pengalaman mengajar yang dilakukan sehari-hari, sehingga guru akan semakin kompeten dalam bidang tugasnya. Jika guru dengan latar belakang akademik yang sesuai dengan bidang tugasnya dan memiliki pengalaman mengajar yang cukup lama, diduga akan berpengaruh positif terhadap kompetensi profesional guru. Kompetensi profesional seorang guru diduga semakin meningkat apabila didukung dengan etos kerja yang tinggi.

Berdasarkan permasalahan tersebut, maka muncullah gagasan bersama untuk melakukan penelitian payung mengenai keterlaksanaan kegiatan membelajarkan aspek penelitian dalam pembelajaran mata pelajaran IPA SMP dan rumpun IPA SMA di Provinsi DIY hubungannya dengan latar belakang guru. Tim penggagas penelitian ini terdiri atas lima orang dengan rincian sebagai berikut: (1) Prof. Dr. Bambang Subali, M.S. sebagai ketua; (2) Desy Aquina, S.Pd sebagai anggota; (3) Camalina Sugiyarti, S.Pd sebagai anggota; (4) Dewi Anggraini, S.Pd sebagai anggota; dan (5) Florentina Maria Panda, S.Pd sebagai anggota. Penelitian ini sangat penting dan menarik, karena belum pernah sebelumnya dilakukan penelitian sejenis.

Pada penelitian ini dibatasi tempat pelaksanaan penelitian di kota Yogyakarta, karena kualitas pendidikan di kota Yogyakarta menjadi tolok ukur bagi daerah lain di Provinsi Yogyakarta. Mengamati kegiatan membelajarkan aspek penelitian dalam pembelajaran biologi hanya di kelas X karena keterampilan berinves- tigasi mulai diajarkan di kelas $\mathrm{X}$, sehingga perlu diteliti lebih lanjut. Keterlaksanaan membelajarkan aspek penelitian hanya dihubungkan dengan aspek latar belakang akademik guru karena kompetensi yang dimiliki guru merupakan salah satu faktor penentu aktualisasi proses untuk mencapai produk pembelajaran. Latar belakang akademik guru dibatasi hanya pada aspek jenjang pendidikan dan keikutsertaan diklat.

Secara terperinci dapat dirumuskan permasalahan sebagai berikut: (1) persepsi guru terhadap keterlaksanaan membelajarkan aspek penelitian dalam pembelajaran biologi SMA kelas X di SMAN se-Kota Yogyakarta di tinjau dari penilaian dokumen, observasi, dan kecocokannya dengan persepsi siswa?; (2) keterlaksanaan kegiatan membelajarkan aspek penelitian dalam pembelajaran biologi SMA kelas $\mathrm{X}$ hubungannya dengan latar belakang akademik guru?

Tujuan penelitian ini adalah untuk mengetahui: (1) persepsi guru terhadap keterlaksanaan membelajarkan aspek penelitian dalam pembelajaran biologi SMA kelas X di SMAN se-Kota Yogyakarta di tinjau dari penilaian dokumen, observasi, dan kecocokannya dengan persepsi siswa; (2) keterlaksanaan kegiatan membelajarkan aspek penelitian dalam pembelajaran biologi SMA kelas X hubungannya dengan latar belakang akademik guru.

Manfaat penelitian ini adalah: (1) bagi lembaga yang diteliti, memberikan masukan tentang keterlaksanaan membelajarkan aspek penelitian sehingga dapat dijadikan dasar dalam membina, meningkatkan, dan mengembangkan kompetensi guru biologi; (2) memberikan rekomendasi kepada Dinas Pendidikan Kota Yogyakarta sebagai bahan pertimbangan evaluasi keterlaksanaan kegiatan membelajarkan aspek penelitian oleh guru biologi kelas X di SMA Negeri; (3) bagi peneliti, memperoleh informasi secara empiris untuk lebih memahami permasalahan keterlaksanaan membelajarkan aspek penelitian berdasarkan latar belakang akademik guru.

Definisi operasional pada penelitian ini adalah sebagai berikut: (1) keterlaksanaan merupakan penampilan aktual dari program, dalam penelitian ini kegiatan membelajarkan aspek penelitian dikatakan terlaksana apabila pada setiap Kompetensi Dasar atau Pokok Bahasan guru membelajarkan aspek penelitian kepada siswa di ruang kelas maupun pada saat siswa melakukan kegiatan eksperimen di laboratorium biologi; (2) aspek penelitian adalah aspek-aspek 
pada SKL (Standar Kompetensi Lulusan) dan keterampilan proses sains yang harus dimiliki siswa SMA mapel biologi yang meliputi: (1) menemukan masalah, (2) merumuskan masalah, (3) menentukan tujuan dan manfaat penelitian, (4) menentukan variabel, (5) mengajukan dan menguji hipotesis, (5) menentukan literatur yang relevan, (6) menentukan dasar teori, (7) menyusun langkah kerja, (8) merancang dan merakit instrumen, (9) menggunakan berbagai peralatan untuk melakukan pengamatan dan pengukuran yang tepat dan teliti, (10) mengumpulkan, mengolah, menafsirkan dan menyajikan data secara sistematis, (11) menganalisis hasil penelitian, (12) menarik kesimpulan sesuai dengan bukti yang diperoleh, dan (13) berkomunikasi ilmiah hasil percobaan secara lisan dan tertulis, yang masing-masing aspek berdiri sendiri dan tidak terintegrasi; (3) latar belakang akademik guru dilihat dari jenjang pendidikan (S-0/S-1/S2/S-3) dan keikutsertaan diklat berdasarkan keluasan wilayahnya (lokal, regional, maupun nasional).

\section{METODE}

Penelitian ini menggunakan jenis penelitian evaluasi. Model evaluasi yang digunakan adalah model Discrepancy dari Provus yaitu melihat apakah terdapat kesenjangan atau tidak antara performance (kemampuan guru dalam membelajarkan aspek penelitian pada siswa) dengan standard (adanya rumusan SK dan KD baik dalam KTSP maupun Kurikulum 2013 yang menuntut siswa dapat merencanakan, melaksanakan, dan melaporkan eksperimen untuk topik tertentu sehingga guru memiliki tanggung jawab untuk mengajarkan aspek penelitian).

\section{Waktu dan Tempat Penelitian}

Penelitian ini dilaksanakan di SMA Negeri se-Kota Yogyakarta, ada sebelas SMA Negeri, namun ada tiga sekolah yang tidak bersedia memberi izin untuk penelitian sehingga penelitian dilakukan di 8 SMA Negeri di Kota Yogyakarta. Penelitian dilakukan pada bulan Januari Juni 2014.

\section{Subjek Penelitian}

Subjek penelitian ini adalah seluruh guru biologi kelas X SMA N se-Kota Yogyakarta sejumlah 8 orang. Diperlukan data pendukung dari siswa kelas $\mathrm{X}$ yang diajar oleh guru yang bersangkutan. Setiap satu sekolah diambil satu kelas secara acak sebagai sampel. Jumlah populasi siswa kelas $\mathrm{X}$ dari 8 SMA Negeri adalah
1180 orang dan yang diambil sebagai sampel sebanyak 270 siswa. Hal ini menggunakan cara yang dikembangkan dari Isaac dan Michael untuk tingkat kesalahan 5\% (Sugiyono, 2010, p.126).

\section{Variabel Penelitian}

Variabel-variabel yang terlibat pada penelitian ini yaitu: (1) variabel bebas yang berupa latar belakang akademik guru diperoleh melalui ijazah (akan diungkap jenjang pendidikannya) dan pelatihan (akan diungkap keikutsertaannya dalam diklat, diklat yang dimaksud dalam penelitian ini lebih difokuskan pada diklat yang berkaitan dengan kegiatan membelajarkan aspek penelitian); (2) variabel intervening yang mencakup pemahaman guru terhadap kemampuan meneliti, dan kesiapan guru dalam mengembangkan RPP yang memuat aspek penelitian; (3) variabel tergayut yang berupa performansi guru dalam hal merencanakan pembelajaran (RPP) dan melaksanakan pembelajaran yang memuat aspek penelitian. Pengelompokkan jenjang pendidikan dan keikutsertaan diklat dapat dilihat pada Tabel 1 dan Tabel 2.

Tabel 1. Kategori Jenjang Pendidikan

\begin{tabular}{cc}
\hline Kategori & Jenjang Pendidikan \\
\hline 1 & $\mathrm{~S}-0$ \\
2 & $\mathrm{~S}-1$ \\
3 & $\mathrm{~S}-2$ \\
4 & $\mathrm{~S}-3$ \\
\hline
\end{tabular}

Tabel 2. Kategori Keikutsertaan Diklat

\begin{tabular}{cl}
\hline Kategori & \multicolumn{1}{c}{ Keikutsertaan Diklat } \\
\hline 1 & $\begin{array}{l}\text { Tidak pernah mengikuti pelatihan } \\
\text { Pernah mengikuti pelatihan hanya di } \\
\text { tingkat lokal saja }\end{array}$ \\
3 & $\begin{array}{l}\text { Pernah mengikuti pelatihan hanya di } \\
\text { tingkat regional saja }\end{array}$ \\
4 & $\begin{array}{l}\text { Pernah mengikuti pelatihan hanya di } \\
\text { tingkat nasional saja }\end{array}$ \\
5 & $\begin{array}{l}\text { Pernah mengikuti pelatihan hanya di } \\
\text { tingkat lokal dan regional }\end{array}$ \\
6 & $\begin{array}{l}\text { Pernah mengikuti pelatihan hanya di } \\
\text { tingkat lokal dan nasional } \\
\text { Pernah mengikuti pelatihan hanya di } \\
\text { tingkat regional dan nasional } \\
\text { Pernah mengikuti pelatihan di tingkat } \\
\text { lokal, regional, dan nasional }\end{array}$ \\
\hline
\end{tabular}

\section{Instrumen, dan Teknik Pengumpulan Data}

Teknik pengumpulan data dalam penelitian ini dilakukan melalui tiga tahap yakni kuesioner, penilaian dokumen, dan observasi. Kuesioner untuk mengetahui data latar belakang akademik guru yang terdiri atas jenjang pendidikan 
dan keikutsertaan diklat, serta untuk mengetahui sejauh mana keterlaksanaan membelajarkan aspek penelitian. Responden kuesioner adalah guru dan siswa. Penilaian dokumen dilakukan terhadap pemuatan aspek penelitian dalam pembelajaran biologi pada RPP, dengan tiga orang penilai. Kegiatan observasi ini dilakukan apabila dari kuesioner dan penilaian dokumen dinyatakan bahwa guru membelajarkan aspek penelitian. Kegiatan observasi digunakan untuk mengamati performansi guru dalam membelajarkan aspek penelitian baik di kelas maupun di laboratorium. Observasi dilakukan oleh tiga observer.

Kisi-kisi dan instrumen pokok mengenai keterlaksanaan membelajarkan aspek penelitian ini disusun oleh tim, dengan ketua dan anggota tim sama seperti tim penggagas penelitian ini.

\section{Validitas dan Reliabilitas Instrumen}

Validitas kuesioner dilakukan dengan menggunakan validitas logis dan empiris. Validitas logis yaitu mencakup validitas isi pertanyaan yang ditentukan atas dasar pertimbangan (judgment) dari pakar. Dari hasil validitas logis, pakar menyarankan agar peneliti mempunyai dasar yang jelas bahwa aspek penelitian memang harus diajarkan pada siswa yang termuat dalam silabus dan RPP sesuai pedoman yang dibuat BSNP. Sementara validitas empiris melalui uji coba untuk menghubungkan performasi sebuah tes terhadap kriteria penampilan tes lainnya. Hasil validitas empiris menunjukkan bahwa instrumen yang dibuat mudah dibaca dan dipahami karena sudah diberikan contoh untuk masingmasing aspek penelitian. Agar instrumen yang dibuat peneliti dapat dikatakan valid, maka terlebih dahulu diujicobakan kepada siswa Kelas XI salah satu SMA negeri di kota Yogyakarta. Uji coba ini menitikberatkan keterpahaman dan keterbacaan instrumen oleh responden. Uji validitas item secara empiris menggunakan pendekatan teori tes klasik (Classical Test Theory atau CTT) dan teori tes modern (Item Respons Theory atau IRT). Bila menggunakan pendekatan teori tes klasik, item dinyatakan sahih sebagai alat ukur jika nilai validitasnya tinggi. Sedangkan, bila menggunakan pendekatan teori tes modern, item dinyatakan sahih sebagai alat ukur jika terpenuhi adanya unidimensional dan dinyatakan fit dengan model dengan batas kisaran INFIT MNSQ dari 0,77 - 1,30 (Adam \& Khoo, 1996, p.30 \& p.90). Karena ketiadaan kuesioner yang sudah terstandarkan untuk memenuhi validitas kriteria, maka digunakan pendekatan teori tes modern yang mensyaratkan adanya unidimensionalitas dan fit item terhadap model sebagaimana yang diuraikan Adam \& Khoo, (1996, p.30 \& p.90) mengenai analisis non tes Rating Scale Model (RSM). Dalam hal ini, itemitem yang ada akan dibagi menurut dimensi dari variabel yang diukur dan pengujian fit item terhadap model.

Validitas lembar penilaian dokumen dilakukan dengan menggunakan validitas logis yang dilakukan untuk pemenuhan validitas isi, yaitu validitas isi yang memuat seluruh unsur penelitian dalam pembelajaran Biologi di SMA yang termuat di dalam lembar penilaian yang ditentukan atas dasar pertimbangan (judgment) dari pakar. Pakar menyarankan agar dalam membuat keterangan alternatif jawaban perlu diperbaiki lagi agar mudah memahaminya.

Validitas instrumen observasi menggunakan validitas logis yang dilakukan untuk pemenuhan validitas isi, yaitu validitas isi yang memuat seluruh unsur penelitian dalam pembelajaran Biologi di SMA yang dapat diobservasi yang ditentukan atas dasar pertimbangan (judgment) dari pakar. Pakar menyarankan agar dalam membuat keterangan alternatif jawaban perlu diperbaiki lagi agar mudah memahaminya.

Perhitungan reliabilitas kuesioner merujuk pada rumus alpha dari Fernandes (1984, p.38) sebagai berikut:

$$
r=\left(\frac{k}{k-1}\right)\left(1-\frac{\sum \sigma_{1}^{2}}{\sigma^{2}}\right)
$$

$\mathrm{r}=$ reliabilitas instrumen

$\mathrm{k}=$ banyaknya butir pertanyaan

$\sum \sigma_{1}^{2}=$ jumlah varians butir

$\sigma^{2}=$ varians total

Pedoman dalam menggunakan Cronbach's Alpha adalah sebagai berikut: (1) koefisien Alpha dibawah 0,6 dianggap mempunyai reliabilitas yang buruk; (2) koefisien Alpha antara 0,6 sampai 0,8 dianggap mempunyai reliabilitas dapat diterima; (3) koefisien Alpha diatas 0,8 dianggap mempunyai reliabilitas yang baik. Perhitungan koefisien reliabilitas instrumen dilakukan dengan menggunakan bantuan komputer berupa program QUEST.

\section{Uji Coba Instrumen}

Uji instrumen dilakukan pada populasi yang memiliki kemiripan karakteristik dan perlakuan namun tidak menjadi subjek penelitian. Hasil uji validitas dan reliabilitas menggunakan program Quest menunjukkan semua item masuk 
dalam batas infit MNSC dalam kisaran 0,77 1,30 , maka semua item dinyatakan fit dengan model atau dalam pandangan teori klasik setara dengan valid. Nilai reliabilitas setelah dianalisis menggunakan program Quest diperoleh Reliability of estimate sebesar 0,91 berarti item mempunyai reliabilitas yang tinggi, sampel uji coba fit dengan item yang diujikan.

\section{Teknik Analisis Data}

Penelitian ini menggunakan analisis data dengan teknik deskriptif kuantitatif. Data dari lembar kuesioner, penilaian dokumentasi, dan observasi dianalisis secara deskriptif kuantitatif dengan menggunakan skor kriteria kemudian dideskripsikan dan diambil kesimpulan terhadap masing-masing komponen atas dasar kriteria yang telah ditentukan. Besarnya skor pada kategori mana, sehingga dapat diketahui posisi masing-masing aspek. Data dideskripsikan dengan mentabulasikan menurut masing-masing variabel.

Teknik kuesioner dengan skala likert untuk mengetahui persepsi guru dan siswa mengenai sejauh mana guru membelajarkan aspek penelitian kepada siswa. Secara garis besar aspek penelitian dibagi menjadi 3 tahap yaitu aspek perencanaan, aspek pelaksanaan, dan aspek pelaporan penelitian. Kriteria penilaian diukur dari 33 butir pernyataan dengan menggunakan skala likert, penskoran yang digunakan adalah skala 5, 4, 3, 2, dan 1. 5 = Hampir selalu dilakukan pada tiap $\mathrm{KD} /$ pokok bahasan, $4=$ Dilakukan pada sebagian besar $\mathrm{KD} /$ pokok bahasan, $3=$ Dilakukan pada sebagian kecil KD/ pokok bahasan, 2 = Hanya dilakukan pada 1 atau 2 $\mathrm{KD} /$ pokok bahasan, $1=$ Belum pernah dilakukan.

Teknik penilaian dokumen untuk mengetahui kemampuan guru dalam merencanakan pembelajaran Biologi yang memuat aspek penelitian. Secara garis besar aspek penelitian dibagi menjadi 3 tahap yaitu aspek perencanaan, aspek pelaksanaan, dan aspek pelaporan penelitian. Kriteria penilaian diukur dari 33 butir pernyataan menggunakan skala likert, penskoran yang digunakan adalah skala $5,4,3,2$, dan $1.5=$ Hampir selalu dilakukan pada tiap KD/pokok bahasan, $4=$ Dilakukan pada sebagian besar $\mathrm{KD} /$ pokok bahasan, 3 = Dilakukan pada sebagian kecil $\mathrm{KD} /$ pokok bahasan, $2=$ Hanya dilakukan pada 1 atau $2 \mathrm{KD} /$ pokok bahasan, $1=$ Belum pernah dilakukan.

Teknik observasi untuk mengetahui keterlaksanaan membelajarkan aspek penelitian oleh guru pada proses pembelajaran Biologi. Secara garis besar aspek penelitian dibagi menjadi 3 tahap yaitu aspek perencanaan, aspek pelaksanaan, dan aspek pelaporan penelitian. Kriteria penilaian pada aspek pelaksanaan proses pembelajaran Biologi ini diukur dari 33 butir pernyataan dengan menggunakan butir pernyataan dengan menggunakan skala likert, penskoran yang digunakan adalah skala $5,4,3,2$, dan $1.5=$ Sangat sesuai dengan RPP, $4=$ Sesuai dengan RPP, 3 = Cukup sesuai dengan RPP, 2 = Tidak sesuai dengan RPP, 1 = Tidak sesuai dengan RPP.

Kriteria penilaian bagian aspek perencanaan penelitian diukur dari 17 butir pernyataan dengan menggunakan skala likert, penskoran yang digunakan adalah skala 5, 4, 3, 2, dan 1 . Skor terendah yang diperoleh dari tiap-tiap respon adalah sebesar 17, sedangkan skor tertinggi adalah sebesar 85. Skor minimum dan maksimum dari datanya adalah sebesar 17 (1 x 17) sampai dengan 85 (5 x 17), sehingga luas jarak sebarannya adalah $85-17=68$. Dengan demikian, Mean idealnya (Mi) sebesar 51, yakni (1/2 $(85+17)$. Hasil perhitungan kriteria tersebut dapat dilihat pada Tabel 3.

Tabel 3. Kriteria Persepsi Guru dan Siswa, Penilaian Dokumen, serta Observasi Mengenai Keterlaksanaan Membelajarkan Aspek Perencanaan Penelitian

\begin{tabular}{cc}
\hline Interval Skor & Interpretasi/ Kriteria \\
\hline$>68-85$ & Hampir selalu dilakukan \\
$>51-68$ & Sering dilakukan \\
$>34-51$ & Jarang dilakukan \\
$17-34$ & Hampir tidak pernah dilakukan \\
\hline
\end{tabular}

Kriteria penilaian bagian aspek pelaksanaan penelitian diukur dari 7 butir pernyataan dengan menggunakan skala likert dengan penskoran yang digunakan adalah skala 5, 4, 3, 2, dan 1. Skor terendah yang diperoleh dari tiaptiap respon adalah sebesar 7, sedangkan skor tertinggi adalah sebesar 35. Skor minimum dan maksimum dari datanya adalah sebesar 7 ( 1 x 7$)$ sampai dengan 35 (5 x 7), sehingga luas jarak sebarannya adalah $35-7=28$. Dengan demikian, Mean idealnya (Mi) sebesar 21, yakni (1/2 $(35+7)$. Hasil perhitungan kriteria tersebut dapat dilihat pada Tabel 4. 
Tabel 4. Kriteria Persepsi Guru dan Siswa, Penilaian Dokumen, serta Observasi Mengenai

Keterlaksanaan Membelajarkan Aspek Pelaksanaan Penelitian

\begin{tabular}{ll}
\hline \multicolumn{1}{c}{ Interval Skor } & \multicolumn{1}{c}{ Interpretasi/ Kriteria } \\
\hline$>28-35$ & Hampir selalu dilakukan \\
$>21-28$ & Sering dilakukan \\
$>14-21$ & Jarang dilakukan \\
$7-14$ & Hampir tidak pernah dilakukan \\
\hline
\end{tabular}

Kriteria penilaian bagian aspek pelaporan penelitian diukur dari 9 butir pernyataan dengan menggunakan skala likert, penskoran yang digunakan adalah skala 5, 4, 3, 2, dan 1 . Skor terendah yang diperoleh dari tiap-tiap respon adalah sebesar 9, sedangkan skor tertinggi adalah sebesar 45. Skor minimum dan maksimum dari datanya adalah sebesar 9 ( 1 x 9) sampai dengan 45 (5 x 9), sehingga luas jarak sebarannya adalah $45-9=36$. Dengan demikian, Mean idealnya (Mi) sebesar 27, yakni $(1 / 2(45+9)$. Hasil perhitungan kriteria tersebut dapat dilihat pada Tabel 5.

Tabel 5. Kriteria Persepsi Guru dan Siswa, Penilaian Dokumen, serta Observasi Mengenai Keterlaksanaan Membelajarkan Aspek Pelaporan Penelitian

\begin{tabular}{cc}
\hline Interval Skor & Interpretasi/ Kriteria \\
\hline$>36-45$ & Hampir selalu dilakukan \\
$>27-36$ & Sering dilakukan \\
$>18-27$ & Jarang dilakukan \\
$9-18$ & Hampir tidak pernah dilakukan \\
\hline
\end{tabular}

\section{HASIL DAN PEMBAHASAN}

Untuk mengetahui tingkat keterlaksanaan kegiatan membelajarkan aspek penelitian dalam pembelajaran Biologi Kelas X SMA negeri seKota Yogyakarta dapat dilakukan dengan mengumpulkan data dari persepsi guru, persepsi siswa, penilaian dokumen, dan observasi. Setelah diperoleh data kemudian dianalisis apakah terdapat kecocokan antara masing-masing komponen tersebut. Hasil persepsi guru, persepsi siswa, penilaian dokumen, dan observasi mengenai keterlaksanaan membelajarkan aspek penelitian dalam pembelajaran Biologi Kelas X SMA negeri se-Kota Yogyakarta disajikan dalam Tabel 6.
Tabel 6. Keterlaksanaan Membelajarkan Aspek Penelitian

\begin{tabular}{cccccc}
\hline \multirow{2}{*}{ No } & Kriteria & \multicolumn{2}{c}{ HSD } & \multicolumn{2}{c}{ SD } \\
\cline { 2 - 6 } & Ditinjau dari & Jumlah & \% & Jumlah & \% \\
\hline 1 & Persepsi guru & 6 & 75 & 2 & 25 \\
2 & Persepsi siswa & 6 & 75 & 2 & 25 \\
3 & Penilaian & 6 & 75 & 2 & 25 \\
4 & dokumen & & 75 & 2 & 25 \\
\hline \multirow{2}{*}{$*)$ HSD $=$ hampir selalu dilakukan, SD = sering dilakukan }
\end{tabular}

Tabel 6 menunjukkan bahwa terdapat kecocokan antara persepsi guru, persepsi siswa, penilaian dokumen dan hasil observasi dalam hal keterlaksanaan kegiatan membelajarkan aspek penelitian dalam pembelajaran Biologi Kelas X SMA negeri se-Kota Yogyakarta. Berdasarkan hasil tersebut diketahui bahwa kegiatan membelajarkan aspek penelitian dalam pembelajaran Biologi Kelas X SMA negeri se-Kota Yogyakarta sudah dilakukan dan sudah sesuai harapan. Hal ini dikarenakan tingkat keterlaksanaan kegiatan membelajarkan aspek penelitian pada kelompok HSD (hampir selalu dilakukan) lebih tinggi dibanding pada kelompok SD (sering dilakukan).

Telah diketahui bahwa persepsi guru merupakan pendapat dari guru yang menilai dirinya sendiri mengenai seberapa jauh guru telah membelajarkan aspek penelitian, yang diharapkan dapat memberikan informasi mengenai tingkat keterlaksanaannya. Persepsi guru tersebut juga diperkuat oleh persepsi siswa yang menunjukkan hasil yang hampir sama. Pernyataan dari siswa mengenai keterlaksanaan kegiatan membelajarkan aspek penelitian sangat diperlukan karena siswa sendirilah yang melihat dan melaksanakan pembelajaran yang dirancang oleh guru dalam memuat aspek-aspek penelitian. Tidak hanya dilihat dari persepsi guru dan siswa saja, tetapi penilaian dokumen dan observasi perlu dilakukan agar terjadi kecocokan dalam hal membelajarkan aspek penelitian. Penilaian dokumen yang dimaksud adalah penilaian yang dilakukan terhadap rencana pembelajaran yang termuat dalam RPP yang dibuat oleh guru. Dalam RPP dapat dilihat aspek-aspek penelitian yang terbagi dalam aspek perencanaan, aspek pelaksanaan, dan aspek pelaporan penelitian. Sehingga dapat dinilai seberapa jauh rencana pembelajaran yang dibuat guru dalam memuat aspek penelitian.

Observasi penting dilakukan karena dapat diamati bagaimana guru membelajarkan aspek penelitian baik di kelas atau di laboratorium sesuai dengan rencana pembelajaran yang telah 
dibuat. Dengan melakukan observasi, observer dapat lebih jelas dalam mengamati kegiatan guru dalam membelajarkan aspek penelitian. Berdasarkan hasil observasi dalam pembelajaran Biologi Kelas X di SMAN se-Kota Yogyakarta menunjukkan bahwa siswa lebih banyak melakukan kegiatan sendiri atau dalam bentuk kelompok dalam memecahkan permasalahan yang dibantu dengan bimbingan guru, sehingga siswa mampu berpikir untuk menemukan masalah dan mengkonstruksi sendiri alternatif-alternatif pemecahan masalah terhadap masalah Biologi yang dipelarinya. Hal ini sesuai dengan hasil penelitian Khanafiyah (2009, p.1) yang menyatakan bahwa dengan menerapkan pendekatan modified free inquiry dalam pembelajaran, kemampuan psikhomotorik mahasiswa menjadi lebih baik, karena mereka terbiasa dalam kegiatan. Misal pembuatan perencanaan, pelaksanaan kegiatan serta pembuatan laporan. Selain itu jenis eksperimen yang dikembangkan menjadi lebih banyak, serta mahasiswa lebih kreatif dalam mengembangkan tujuan eksperimen. Temuan tersebut juga diperkuat oleh Nurochma (2013, p.1) yang menyatakan bawah strategi pembelajaran Guided Inquiry berpengaruh nyata dalam meningkatkan hasil belajar biologi ranah kognitif.

Dalam strategi pembelajarannya, guru Biologi di SMA negeri se-Kota Yogyakarta telah menerapkan berbagai metode, pendekatan, dan model, misalnya metode diskusi, metode eksperimen, pendekatan discovery dan pendekatan pemecahan masalah. Berbagai macam strategi tersebut dapat digunakan sesuai dengan karakteristik siswa dan materi yang akan diberikannya. Variasi strategi pembelajaran perlu dilakukan agar siswa memperoleh lebih banyak keterampilan-keterampilan proses sains baik dalam bentuk parsial maupun terintegrasi. Contohnya melalui pendekatan penemuan, siswa dapat mengasimilasikan sesuatu konsep atau suatu prinsip, misalnya dalam proses mengamati, membuat hipotesis, menjelaskan pengukuran, membuat tabel dan grafik serta menginterpretasi data (Carin \& Sund, 1989, p.135). Sejalan dengan hal tersebut, hasil penelitian Yadav (2013, p.1) menyatakan bahwa siswa yang belajar melalui pendekatan laboratorium lebih baik dalam hal keterampilan proses, prestasi dan tes praktek.

Selanjutnya untuk mengungkap latar belakang akademik guru yang berupa kategori jenjang pendidikan (S-0/S-1/S-2/S-3) dan kategori keikutsertaan diklat berdasarkan jangkauan wi-layahnya (lokal, regional, nasional) digunakan kuesioner. Pengelompokkan guru berdasarkan jenjang pendidikan dan keikutsertaan diklat disajikan pada Tabel 7 dan Tabel 8.

Tabel 7. Pengelompokkan Guru Berdasarkan Jenjang Pendidikan Guru

\begin{tabular}{c|c|c}
\hline Jenjang Pendidikan & Jumlah Guru & Persen \\
\hline S-1 & 7 & 88 \\
S-2 & 1 & 12 \\
\hline
\end{tabular}

Tabel 7 menunjukkan bahwa semua guru biologi kelas X di SMA N se-Kota Yogyakarta telah memiliki ijazah S-1 dan hanya 1 guru yang telah memperoleh ijazah S-2.

Tabel 8. Jumlah Guru Dikelompokkan Berdasarkan Keikutsertaan Diklat

\begin{tabular}{lcc}
\hline \multicolumn{1}{c}{ Keikutsertaan diklat *) } & $\begin{array}{l}\text { Jumlah } \\
\text { (orang) }\end{array}$ & Persen \\
\hline $\begin{array}{l}\text { Hanya mengikuti 1 atau 2 } \\
\text { jenis diklat } \\
\text { Mengikuti semua jenis }\end{array}$ & 3 & 37 \\
diklat & 5 & 62 \\
\hline *) hanya mengikuti diklat 1 jenis/2 jenis dan \\
$\begin{array}{l}\text { mengikuti 3 jenis diklat/mengikuti semua jenis diklat. } \\
\text { Diklat berdasarkan keluasan wilayahnya dapat } \\
\text { berupa diklat lokal, regional, dan nasional. }\end{array}$
\end{tabular}

Tabel 8 menunjukkan bahwa terdapat 3 guru biologi kelas X di SMA N se-Kota Yogyakarta yang hanya mengikuti satu atau dua jenis diklat dan 5 guru yang mengikuti tiga jenis diklat atau mengikuti semua jenis diklat.

Selanjutnya untuk mengetahui tingkat keterlaksanaan kegiatan membelajarkan aspek penelitian dalam pembelajaran Biologi Kelas X SMA negeri se-Kota Yogyakarta berdasarkan latar belakang akademik guru dapat dilakukan dengan mengumpulkan data dari persepsi guru, persepsi siswa, penilaian dokumen, dan observasi. Setelah diperoleh data kemudian dianalisis apakah terdapat kecocokan antara masing-masing komponen tersebut. Hasil persepsi guru, persepsi siswa, penilaian dokumen, dan observasi mengenai keterlaksanaan membelajarkan aspek penelitian dalam pembelajaran Biologi Kelas X SMA negeri se-Kota Yogyakarta berdasarkan latar belakang akademik guru (jenjang pendidikan dan keikutsertaan diklat) disajikan dalam Tabel 9 dan Tabel 10 berikut. 
Jurnal Inovasi Pendidikan IPA, 2 (1), 2016 - 9

Desy Aquina, Bambang Subali

Tabel 9. Keterlaksanaan Kegiatan Membelajarkan Aspek Penelitian Berdasarkan Jenjang Pendidikan Guru

\begin{tabular}{|c|c|c|c|c|c|}
\hline $\begin{array}{c}\text { Ditinjau } \\
\text { dari }\end{array}$ & $\begin{array}{c}\text { Jenjang } \\
\text { pendidikan }\end{array}$ & Kriteria & $\begin{array}{c}\text { Aspek perencanaan } \\
(\%)\end{array}$ & $\begin{array}{c}\text { Aspek pelaksanaan } \\
(\%)\end{array}$ & $\begin{array}{c}\text { Aspek pelaporan } \\
(\%)\end{array}$ \\
\hline \multirow{4}{*}{$\begin{array}{l}\text { Persepsi } \\
\text { guru }\end{array}$} & \multirow{2}{*}{ S-1 } & HSD & 62 & 50 & 62 \\
\hline & & SD & 25 & 37 & 25 \\
\hline & \multirow{2}{*}{$S-2$} & HSD & 13 & 13 & 13 \\
\hline & & SD & 0 & 0 & 0 \\
\hline \multirow{4}{*}{$\begin{array}{l}\text { Persepsi } \\
\text { siswa }\end{array}$} & \multirow{2}{*}{ S-1 } & HSD & 62 & 62 & 62 \\
\hline & & SD & 25 & 25 & 25 \\
\hline & \multirow{2}{*}{ S-2 } & HSD & 13 & 13 & 13 \\
\hline & & SD & 0 & 0 & 0 \\
\hline \multirow{4}{*}{$\begin{array}{l}\text { Penilaian } \\
\text { dokumen }\end{array}$} & \multirow{2}{*}{ S-1 } & HSD & 62 & 62 & 50 \\
\hline & & SD & 25 & 25 & 37 \\
\hline & \multirow[b]{2}{*}{ S-2 } & HSD & 13 & 13 & 13 \\
\hline & & SD & 0 & 0 & 0 \\
\hline \multirow{4}{*}{ Observasi } & \multirow{2}{*}{ S-1 } & HSD & 50 & 62 & 62 \\
\hline & & SD & 37 & 25 & 25 \\
\hline & \multirow{2}{*}{$S-2$} & HSD & 13 & 13 & 13 \\
\hline & & SD & 0 & 0 & 0 \\
\hline
\end{tabular}

*) $\mathrm{HSD}=$ hampir selalu dilakukan, $\mathrm{SD}$ = sering dilakukan

Tabel 10. Keterlaksanaan Kegiatan Membelajarkan Aspek Penelitian

Berdasarkan Keikutsertaan Diklat

\begin{tabular}{|c|c|c|c|c|c|}
\hline Ditinjau dari *) & $\begin{array}{c}\text { Keikutsertaan } \\
\text { diklat } *)\end{array}$ & Kriteria & $\begin{array}{c}\text { Aspek } \\
\text { perencanaan (\%) }\end{array}$ & $\begin{array}{c}\text { Aspek } \\
\text { pelaksanaan (\%) }\end{array}$ & $\begin{array}{c}\text { Aspek } \\
\text { pelaporan }(\%)\end{array}$ \\
\hline \multirow{4}{*}{ Persepsi guru } & \multirow{2}{*}{1 atau 2 jenis } & HSD & 13 & 0 & 13 \\
\hline & & SD & 25 & 38 & 25 \\
\hline & \multirow{2}{*}{3 jenis } & HSD & 62 & 62 & 62 \\
\hline & & SD & 0 & 0 & 0 \\
\hline \multirow{4}{*}{ Persepsi siswa } & \multirow{2}{*}{1 atau 2 jenis } & HSD & 13 & 13 & 13 \\
\hline & & SD & 25 & 25 & 25 \\
\hline & \multirow{2}{*}{3 jenis } & HSD & 62 & 62 & 62 \\
\hline & & SD & 0 & 0 & 0 \\
\hline \multirow{4}{*}{ Penilaian dokumen } & \multirow{2}{*}{1 atau 2 jenis } & HSD & 13 & 13 & 0 \\
\hline & & SD & 25 & 25 & 38 \\
\hline & \multirow{2}{*}{3 jenis } & HSD & 62 & 62 & 62 \\
\hline & & SD & 0 & 0 & 0 \\
\hline \multirow{4}{*}{ Observasi } & \multirow{2}{*}{1 atau 2 jenis } & HSD & 0 & 13 & 13 \\
\hline & & SD & 38 & 25 & 25 \\
\hline & \multirow{2}{*}{3 jenis } & HSD & 62 & 62 & 62 \\
\hline & & SD & 0 & 0 & 0 \\
\hline
\end{tabular}

*) HSD = hampir selalu dilakukan, $\mathrm{SD}$ = sering dilakukan

**) hanya mengikuti diklat 1 jenis/2 jenis dan mengikuti 3 jenis diklat/mengikuti semua jenis diklat. Diklat berdasarkan keluasan wilayahnya dapat berupa diklat lokal, regional, dan nasional.

Tabel 9 menunjukkan bahwa keterlaksanaan kegiatan membelajarkan aspek penelitian pada mata pelajaran biologi kelas X SMA N sekota Yogyakarta tidak bergantung pada jenjang pendidikan guru. Kelompok jenjang pendidikan S-1 masuk kriteria hampir selalu dilakukan dan sering dilakukan dalam hal membelajarkan aspek penelitian pada aspek perencanaan, aspek pelaksanaan, maupun aspek pelaporan. Sedangkan, kelompok jenjang pendidikan S-2 masuk pada kriteria hampir selalu dilakukan dalam hal membelajarkan aspek penelitian pada aspek perencanaan, aspek pelaksanaan, maupun aspek pelaporan.

Tabel 10 menunjukkan bahwa keterlaksanaan kegiatan membelajarkan aspek penelitian pada mata pelajaran biologi kelas X SMA N sekota Yogyakarta bergantung pada keikutsertaan diklat. Kelompok pernah mengikuti 1 atau 2 jenis diklat masuk kriteria hampir selalu dilakukan dan sering dilakukan dalam hal membelajarkan aspek penelitian pada aspek perencanaan, aspek pelaksanaan, maupun aspek pelaporan. Sedangkan, kelompok pernah mengikuti semua jenis 
diklat masuk pada kriteria hampir selalu dilakukan dalam hal membelajarkan aspek penelitian pada aspek perencanaan, aspek pelaksanaan, maupun aspek pelaporan.

Berdasarkan hasil tersebut dapat diketahui bahwa dari kategori jenjang pendidikan, untuk kelompok guru S-2, tingkat keterlaksanaan dalam membelajarkan aspek penelitian lebih tinggi dibanding kelompok S-1 baik dalam aspek perencanaan, aspek pelaksanaan, maupun aspek pelaporan penelitian. Sedangkan, jika tinjau dari kategori keikutsertaan diklat, kelompok guru yang pernah mengikuti diklat di tingkat lokal, regional dan nasional, untuk tingkat keterlaksanaan dalam membelajarkan aspek penelitian lebih tinggi dibanding kelompok guru yang pernah mengikuti diklat hanya di tingkat lokal dan regional baik dalam aspek perencanaan, aspek pelaksanaan, maupun aspek pelaporan penelitian. Hal tersebut menunjukkan bahwa tingkat keterlaksanaan kegiatan membelajarkan aspek penelitian bergantung pada latar belakang akademik. Temuan ini memperkuat pendapat yang menyatakan bahwa latar belakang pendidikan dan pengalaman mengajar adalah dua aspek yang mempengaruhi kompetensi seorang guru di bidang pendidikan dan pengajaran (Djamarah, 1997, p.17). Hal tersebut senada dengan hasil penelitian Lai (2009, p.1) yang menunjukkan bahwa kualitas sekolah dan kualifikasi guru memberikan pengaruh yang kuat dalam hal prestasi siswa.

Hasil penelitian Muhamad Syaikhul Alim (2010, p.23) yang menunjukkan bahwa terdapat pengaruh yang signifikan dan positif dari kualifikasi pendidikan, keikutsertaan diklat dan sikap pada profesi secara simultan terhadap kompetensi guru. Namun, jika dilihat lebih rinci dari hasil kuesioner guru dan siswa, penilaian dokumen dan observasi, menunjukkan bahwa latar belakang akademik yang berupa kategori keikutsertaan diklat lebih memberikan pengaruh terhadap kemampuan guru dalam membelajarkan aspek penelitian dibandingkan dengan kategori jenjang pendidikan. Hal ini sejalan dengan penelitian Purnamawati $(2009$, p.1) yang melihat ada pengaruh yang signifikan antara persepsi efektivitas diklat guru terhadap kompetensi mengajar.

Hal ini dapat terjadi karena ilmu pendidikan dan ilmu murni yang diperoleh pada jenjang S-1 dan S-2 tidak jauh berbeda (jika S-1 dan S-2 linear), diklat yang diikuti oleh guru misalnya dalam bentuk seminar yang memberikan pelatihan-pelatihan (terutama yang berhu- bungan dengan kegiatan membelajarkan aspek penelitian) dapat memberikan pengalaman bagi guru untuk dapat mengajar secara profesional dan sesuai hakikat Sains yaitu dengan membelajarkan aspek penelitian.

Hasil penelitian Miarso (2008, p.6) menunjukkan bahwa pendidikan dan latihan guru diselenggarakan sebagai bagian dari upaya meningkatkan mutu tenaga kependidikan. Melalui diklat inovasi-inovasi baru dalam dunia pendidikan dapat disebarkan. Hal ini mengingat perkembangan dalam dunia pendidikan sangat pesat sehingga guru dituntut terus-menerus memperbaharui wawasannya baik berkaitan dengan kebijakan pendidikan maupun pembelajaran. Dengan diklat pula guru dapat meningkatkan pengetahuan (Knowledge), keterampilan (Skill) dan sikap (Attitude). Tiga hal ini merupakan inti dari kompetensi guru.

\section{SIMPULAN DAN SARAN}

\section{Simpulan}

Sesuai dengan deskripsi hasil penelitian dan pembahasan, dapat disimpulkan hal-hal sebagai berikut: (1) 75\% guru biologi kelas $X$ di SMA N se-Kota Yogyakarta telah membelajarkan aspek penelitian pada kriteria hampir selalu dilakukan dan 25\% guru biologi membelajarkan aspek penelitian pada kriteria sering dilakukan; (2) keterlaksanaan kegiatan membelajarkan aspek penelitian dalam pembelajaran biologi kelas X SMAN se-Kota Yogyakarta bergantung pada latar belakang akademik guru khususnya kategori keikutsertaan diklat.

\section{Saran}

Para guru biologi diharapkan sering mengikuti diklat baik yang diselenggarakan dari pihak sekolah, dinas pendidikan kota, maupun departemen pendidikan khususnya yang berkaitan dengan kegiatan membelajarkan aspek penelitian agar guru lebih kompeten lagi dalam membelajarkan aspek penelitian.

\section{DAFTAR PUSTAKA}

Adams, R.J. \& Kho, S.T. (1996). Quest the interactive test analysis system version 2.1. Victoria: The Australian Council for Educational Research.

Alim, S. (2010). Pengaruh kualifikasi pendidikan, keikutsertaan diklat dan sikpa pada profesi terhadap kompetensi guru PAI SD di Kabupaten Pekalongan. Online at 
Jurnal Inovasi Pendidikan IPA, 2 (1), 2016 - 11

Desy Aquina, Bambang Subali

http://eprints.walisongo.ac.id/147/1/Syaik hulAlim_Tesis_Sinopsis.pdf (Tanggal 3 Juni 2014).

Bryce, T.G.K., McCall, J., MacGregor, J., Robertson, I.J., \& Weston, R.A.J. (1990). Techniques for assessing process skills in practical science: teacher's guide. Oxford: Heinemann Instructional Books.

Carin, A.A. \& Sund, R.B. (1989). Teaching science through discovery $\left(6^{\text {th }} \mathrm{ed}\right)$. Columbus: Merrill Publishing Company.

Depdiknas. (2006). Peraturan Menteri Pendidikan Nasional Republik Indonesia Nomor 22 Tahun 2006 tentang Standar Isi untuk Satuan Pendidikan Dasar dan Menengah. Depdiknas. Jakarta.

Depdiknas. (2009). Peraturan Pemerintah Republik Indonesia Nomor 41 Tahun 2009 tentang Tunjangan Profesi Guru dan Dosen, Tunjangan Khusus Guru dan Dosen, serta Tunjangan Kehormatan Profesor. Depdiknas. Jakarta.

Djamarah, S.B. (1994). Prestasi belajar dan kompetensi guru. Surabaya: Usaha Nasional.

Fernandes, H.J.X. (1984). Evaluation of education programs. Jakarta: National Education Paln.

Lai, F., Sadoulet, E., \& de Janvry, A. (2009). The contributions of school quality and teacher qualifications to student performance: Evidence from a natural experiment in beizing middle schools. Journal of Human Resources. Online at: http://gspp.berkeley.edu/assets/uploads/re
search/pdf/SchoolEffectJHR.pdf (17 Juni 2014).

Miarso, Y. (2008). Peningkatan kualifikasi guru dalam perspektif teknologi pendidikan, Makalah disampaikan dalam Semiloka di UNNES, 8 Mei 2008, hal. 6.

NSES. (1996). National science education standards. Washington DC: National Academic Press.

Purnamawati. (2009). Pengaruh persepsi efektifitas diklat guru terhadap kompetensi mengajar pada mata pelajaran biologi di MAN. Online at http://bdkpadang.kemenag.go.id/index.ph $p$ ? option $=$ com_content $\&$ view $=$ article $\& i d$ $=545$ : rini $2 \&$ catid $=41$ : top -headlines (diakses tanggal 19 juni 2014).

Rezba, R.J., Sparague, C.S., Fiel, R.L., Funk, H.J., Okey, J.R., \& Jaus, H.H. (1995). Learning and assessing science process skills. $3^{\text {rd }}$ ed. Lowa: Kendall/ Hunt Publishing Company.

Sugiyono. (2010). Metode penelitian kuantitatif kualitatif dan $R \& D$. Bandung: Alfabeta.

Yadav, B., \& Mishra, S.K. (2013). A study of the impact of laboratory approach on achievement and process skills in science among is standard students. International Journal of Scientific and Research Publications, Volume 3, Issue 1, January 2013 ISSN 2250-3153. Online at http://www.ijsrp.org/research-paper1301/ijsrp-p1382.pdf (diakses tanggal 19 juni 2014). 